\title{
LEF1 Induces DHRS2 Gene Expression in Human Acute Leukemia Jurkat T-Cells
}

\author{
Insan Akut Lenfoblastik Lösemi T-hücre Soyu Jurkat hücrelerinde LEF1, DHRS2 Gen \\ Ekspresyonunu Indükler
}

\author{
(D) Sema Sırma Ekmekci, (D) Zeliha Emrence, (D) Neslihan Abacı, (D) Melda Sarıman, (D) Burcu Salman, (D) Cumhur Gökhan Ekmekci, \\ (D) Çağrı Güleç
}

Istanbul University, Aziz Sancar Institute of Experimental Medicine, Department of Genetics, Istanbul, Turkey

\section{Abstract}

Objective: T-cell acute lymphoblastic leukemia (T-ALL) is an aggressive disease resulting from the accumulation of genetic changes that affect the development of T-cells. The precise role of Iymphoid enhancerbinding factor 1 (LEF1) in T-ALL has been controversial since both overexpression and inactivating LEF1 mutations have been reported to date. Here, we investigate the potential gene targets of LEF1 in the Jurkat human T-cell leukemia cell line.

Materials and Methods: We used small interfering RNA (siRNA) technology to knock down LEF1 in Jurkat cells and then compared the gene expression levels in the LEF1 knockdown cells with nontargeting siRNA-transfected and non-transfected cells by employing microarray analysis.

Results: We identified DHRS2, a tumor suppressor gene, as the most significantly downregulated gene in LEF1 knockdown cells, and we further confirmed its downregulation by real-time quantitative polymerase chain reaction ( $q R T-P C R$ ) in $m R N A$ and at protein level by western blotting.

Conclusion: Our results revealed that DHRS2 is positively regulated by LEF1 in Jurkat cells, which indicates the capability of LEF1 as a tumor suppressor and, together with previous reports, suggests that LEF1 exhibits a regulatory role in T-ALL via not only its oncogenic targets but also tumor suppressor genes.

Keywords: T-cell acute lymphoblastic leukemia, p53, DHRS2, LEF1, SiRNA

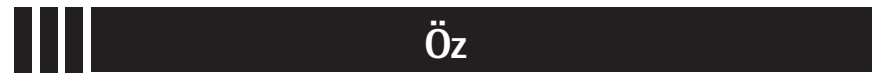

Amaç: T-hücreli akut lenfoblastik lösemi (T-ALL), T-hücrelerinin gelişimini etkileyen genetik değişikliklerin birikmesinden kaynaklanan agresif bir hastalıktır. Bugüne kadar lymphoid enhancer-binding factor 1'in (LEF1) hem inaktive edici mutasyonları hem de aşırı ekspresyonu bildirildiğinden T-ALL gelişiminde rolü tartışmalıdır. Bu çalışmada, insan T hücreli lösemi hücre soyu olan Jurkat hücrelerinde LEF1'in potansiyel hedef genleri araştırıldı.

Gereç ve Yöntemler: Jurkat hücrelerinde küçük engelleyici RNA (siRNA) teknolojisi ile LEF1 baskılandı ve mikroarray analizi ile LEF1 baskılanmış hücrelerdeki gen ekspresyon seviyeleri, negatif kontrol siRNA (hedefsiz siRNA) ile transfekte edilmiş hücrelerdeki gen ekspresyon seviyeleri ile karşılaştırıldı.

Bulgular: LEF1 baskılanmış hücrelerde en önemli seviyede expresyonu azalan gen tümör baskılayıcı DHRS2 geni olarak belirlendi. Ayrıca bu bulgu hem mRNA seviyesinde gerçek zamanlı kantitatif polimeraz zincir reaksiyonu (qRT-PCR) ile hem de protein seviyesinde western blot ile doğrulandı.

Sonuç: Bu bulgular DHRS2'nin Jurkat hücrelerinde LEF1 tarafından pozitif olarak düzenlendiğini göstererek $L E F 1$ 'in tümör baskılayıcı kapasitesi olduğuna işaret etmektedir ve daha önceki çalışmalarda bildirilen sonuçlarla birlikte, $L E F 1$ 'in hem onkojenik hedefleri hem de tümör baskılayıcı hedefleri aracılığıyla T-ALL'de düzenleyici bir rol oynadığını ileri sürmektedir.

Anahtar Sözcükler: T-hücreli akut lenfoblastik lösemi, p53, DHRS2, LEF1, siRNA

\section{Introduction}

T-cell acute lymphoblastic leukemia (T-ALL) is a malignancy associated with a significant risk of relapse and poor prognosis
[1]. T-ALL represents approximately $25 \%$ of adult and $15 \%$ of pediatric ALL patients [2]. Although the prognosis of T-ALL has gradually improved over the years due to modern treatment protocols, resistance and relapse still remain major challenges in

๑Copyright 2020 by Turkish Society of Hematology

Turkish Journal of Hematology, Published by Galenos Publishing House

口: Address for Correspondence/Yazışma Adresi: Sema Sırma Ekmekci, PhD, İstanbul University, Aziz Sancar Institute of Experimental Medicine, Department of Genetics, İstanbul, Turkey

Phone : +90 5068609999

E-mail : sirmasem@istanbul.edu.tr ORCID: orcid.org/0000-0002-1201-7542

Received/Geliş tarihi: April 1, 2020 Accepted/Kabul tarihi: June 23, 2020 
treatment. Thus, our understanding of molecular pathogenesis and the classification of patients can improve treatment outcomes and thereby increase success rates [3,4]. Activating mutations in NOTCH1 or inactivating mutations in its negative regulator (FBXW7) occur in about $60 \%$ of T-ALL cases $[5,6,7,8]$. Activation of the NOTCH signaling pathway cooperates with loss of p16/INK4A and p14/ARF. In addition, translocations in oncogenes, such as LIM-only domain ( $L M O)$ genes, homeobox (HOX) genes, MYC, and MYB, frequently place these genes under the control of strong $T$ cell-specific enhancers, thus causing aberrant overexpression $[2,5]$.

Lymphoid enhancer-binding factor 1 (LEF1), a downstream transcriptional regulator of the $\mathrm{Wnt} / \beta$-catenin pathway, regulates many cell cycle regulatory and cellular proliferation genes [9]. LEF1 can also modulate gene transcription independently [10]. Previous studies have shown that LEF1 plays a crucial role in normal hematopoiesis $[9,11]$. Defective pro-B cell survival and proliferation have been shown in LEF1 knockout mice. Overexpression of LEF1 in bone marrow progenitors results in B-lymphoblastic and acute myeloid lymphoma in recipient animals [11]. In leukemia and solid tumors, abnormal changes in LEF1 expression have been reported in several studies $[12,13,14,15]$.

The findings on the prognostic significance of LEF1 expression show inconsistency among previously reported studies. For example, LEF1 expression has been found to be associated with poor prognosis in adult precursor B-cell acute lymphoblastic leukemia and chronic lymphocytic leukemia $[14,16,17]$, while overexpression of LEF1 has been determined as a favorable prognostic factor in childhood ALL and acute myeloid leukemia $[13,18,19,20]$.

Many gene targets of LEF1 and their associated pathways have been identified. However, its precise role in T-ALL has not been clarified yet. While some studies have shown an increased expression of LEF1 in both premalignant thymocytes and T-ALL [16], others have reported the deletion of the LEF1 gene accompanied with NOTCH1 and PTEN mutations, biallelic INK4A/ARF (CDKN2A) deletions, or activating PI3K or AKT gene mutations in T-ALL $[16,21,22]$. These contradictory findings necessitate further studies to understand the molecular mechanism of LEF1 in T-ALL.

In this study, we have investigated LEF1-regulated genes in Jurkat, a well-characterized human $\mathrm{T}$ acute lymphoblastic leukemia cell line that is widely used in a variety of studies to understand T-cell biology and T-cell signaling. The aim of our study was to identify potentially critical LEF1-regulated genes as well as related molecular signaling pathways using the Jurkat line as model cells.

\section{Materials and Methods}

\section{Cell Culture}

Jurkat cells were cultured at $37{ }^{\circ} \mathrm{C}$ with $5 \% \mathrm{CO}_{2}$ in RPMI-1640 medium (Lonza, Basel, Switzerland) containing 10\% fetal bovine serum (Capricorn Scientific, Ebsdorfergrund, Germany), 100 $\mathrm{U} / \mathrm{mL}$ penicillin, $100 \mathrm{mg} / \mathrm{mL}$ streptomycin (GIBCO, Thermo Fisher Scientific, Waltham, MA, USA) and $2 \mathrm{mM}$ L-glutamine.

\section{LEF1 Small Interfering RNA (siRNA) Transfection}

Jurkat cells were transfected with 100 nM LEF1 siRNA (SMARTpool ON-TARGET plus siRNA, Dharmacon, Lafayette, CO, USA), which targets both long (transcript variant 1, NCBI ID: NM_016269.5) and short isoforms (transcript variants 2, 3, 4; NCBI IDs: NM_001130713.2,NM_001130714.2, NM_001166119.1, respectively) of LEF1 or $100 \mathrm{nM}$ non-targeting siRNA (SMARTpool ON-TARGET plus siRNA, Dharmacon) with HiPerFect transfection reagent (OIAGEN GmbH, Hilden, Germany) according to the manufacturer's protocol and cultured for 24 and $48 \mathrm{~h}$.

\section{RNA Isolation}

Total RNA was isolated from Jurkat cells using the RNeasy Mini Kit (OIAGEN) in accordance with the manufacturer's instructions. RNA concentrations were measured using a spectrophotometer (NanoDrop ND-1000, Thermo Scientific, Waltham, MA, USA).

\section{Real-Time Quantitative PCR (qRT-PCR)}

LEF1 siRNA knockdown and microarray results were confirmed by qRT-PCR. Reverse transcription was performed using random hexamers, total RNA, and the Transcriptor First Strand cDNA Synthesis Kit (Roche Life Science, Mannheim, Germany) following the manufacturer's manual. To quantify the gene expression, primers specific to the LEF1 gene, DHRS2 gene, and housekeeping TATA binding protein gene (TBP) were designed. qRT-PCR was performed using LightCycler 480 SYBR Green I Mix (Roche) and LightCycler 480 Instrument II (Roche) under the following PCR conditions: $95{ }^{\circ} \mathrm{C}$ for $5 \mathrm{~min}, 95{ }^{\circ} \mathrm{C}$ for 20 $\mathrm{s}, 64{ }^{\circ} \mathrm{C}$ for $20 \mathrm{~s}$, and $72{ }^{\circ} \mathrm{C}$ for $15 \mathrm{~s}$ ( 45 cycles). Forward and reverse primers (5'-3') were as follows: TBP-forward: ACT TGA CCT AAA GAC CAT TGC AC and TBP-reverse: CTT GAA GTC CAA GAA CT AGC TGG; DHRS2-forward: CGA CT CCT GGT GTG CAG and DHRS2-reverse: GT CTC CAT GTA GGG CAG C; LEF1forward TGG TGC AGC CAT CCC ATG and LEF1-reverse CGT GAT GGG ATA TAC AGG CTG ACC. Quantification was performed using the relative standard curve method. Each experiment was 
performed in triplicate. Gene expressions were normalized using the housekeeping gene TBP.

\section{Microarray}

Microarray experiments were performed using the Affymetrix GeneChip ${ }^{\circledR}$ 3' IVT Express Kit (Affymetrix, Santa Clara, CA, USA). Sample preparation was conducted in accordance with the manufacturer's protocol. Fragmented end-labeled cDNA was hybridized onto the Affymetrix GeneChip ${ }^{\circledR}$ HG-U133 Plus 2.0 Array according to Affymetrix's standard procedure. After hybridization, the chip was stained and washed in the GeneChip Fluidics Station 450 (Affymetrix) and scanned by GeneChip Array Scanner 3000 G7 (Affymetrix). Expression signals were extracted and normalized using the Expression Console (Affymetrix), applying the robust multichip average (RMA) normalization method. The microarray expression data generated in this study are available in the NCBI Gene Expression Omnibus database (GEO; htt://www.ncbi.nlm.nih.gov/geo/) [23] under accession number GSE129917.

\section{Microarray Data Analysis}

Differential gene expression analyses were performed using the limma package in R. One-way ANOVA was applied to the RMA expression values in order to determine whether genes were differentially expressed between three groups. Multiple-testing correction was applied to the p-values of the F-statistics to adjust the false discovery rate [24]. Expression level differences with $p$-values (FDR-corrected) of $<0.05$ and fold changes of $>2$ were considered significant. Morpheus (https://software. broadinstitute.org/morpheus) was used for the heatmap visualization of gene expression level differences. The Database for Annotation, Visualization, and Integrated Discovery (DAVID) $[25,26]$ web-based tool was used for the biological interpretation of differentially expressed genes. The identified genes were classified based on Gene Ontology Resource [27] annotations and associated pathways were determined using the Kyoto Encyclopedia of Genes and Genomes (KEGG) [28].

\section{Protein Isolation and Western Blotting}

Western blotting was performed to detect LEF1 and DHRS2 protein expression in the cells. All protein samples were prepared from a pool of siRNA-treated culture cells (three wells), which were homogenized and treated with a RIPA lysis buffer system (Santa Cruz Biotechnology, Santa Cruz, CA, USA) on ice. $\beta$-Actin was used as an internal control. The protein concentrations were quantified using the Pierce BCA Protein Assay Kit (Thermo Fisher Scientific). A total of $15 \mu \mathrm{g}$ of proteins were separated in 4\%12\% Bis-Tris gels (Nupage Novex, Life Technologies, Bleiswijk, the Netherlands) and then transferred onto a nitrocellulose membrane using i-Blot Gel transfer stacks (Novex, Life
Technologies). After incubation with blocking buffer (5\% BSA) for $1 \mathrm{~h}$ at room temperature, western blotting was performed using primary antibodies against p53 (dilution, 1:100, D0-1 sc126, Santa Cruz), LEF1 (dilution, 1:250, sc8592, Santa Cruz), DHRS2 (dilution, 1:200, abcam, ab83254), and $\beta$-actin (1:1000, I-19R sc1616K, Santa Cruz) by overnight incubation at $4{ }^{\circ} \mathrm{C}$. After a washing step, the HRP-conjugated secondary goat anti-mouse antibody for $p 53$ (1:3,000, ab97023, abcam), rabbit anti-goat ab for $\operatorname{LEF1}(1: 2,000$ abcam, ab6741), goat anti-rabbit for $\beta$-actin, and DHRS2 (1:5,000, Abbkine A21020-1, Abbkine Scientific, Redlands, CA, USA) were added and incubated for $1 \mathrm{~h}$ at room temperature. Bands were visualized by the WesternBright Sirius system (Advansista, Menlo Park, CA, USA) and analyzed using an imaging system (Wealtec Keta, Wealtec Bioscience Co., Ltd., New Taipei City, Taiwan). For protein quantification, densitometric analyses were done using Image J software (http://rsbweb.nih. gov/ij/index.html).

\section{Statistical Analysis}

SPSS 17.0 (SPSS Inc., Chicago, IL, USA) was used for data analyses. For both LEF1 and DHRS2, mRNA expression level differences between study groups were assessed by Student's t-test. Values of $p<0.05$ were considered statistically significant.

\section{Results}

In order to assess the efficiency of LEF1 suppression after the transfection of Jurkat cells with LEF1 siRNA, we determined the mRNA levels of LEF1 by real-time polymerase chain reaction (qRT-PCR). Twenty-four hours after transfection, we observed an approximately $74.7 \%$ reduction in LEF1 siRNA-transfected (siLEF1) cells compared to non-targeting siRNA-transfected (siNT) cells (Figure 1).

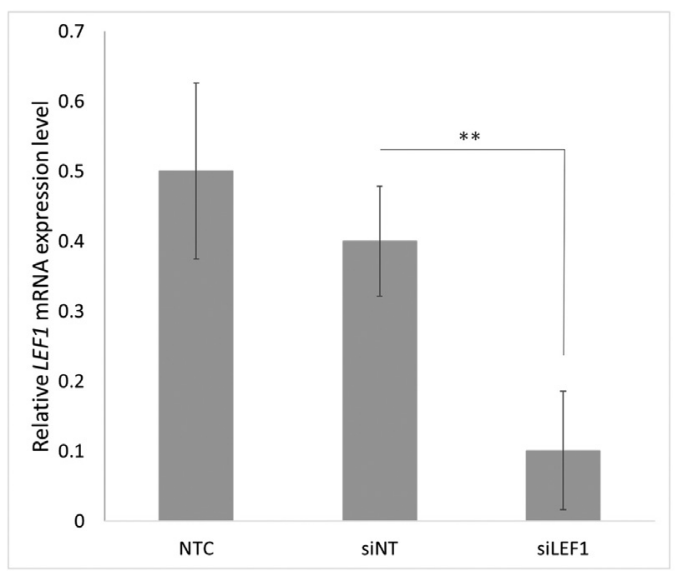

Figure 1. Expression of LEF1 siRNA-transfected Jurkat cells by quantitative PCR. NTC: Non-transfected cells, siNT: non-targeting siRNA-transfected cells, siLEF1: LEF1 siRNA-transfected cells. **: $\mathrm{p}=0.013$. 
We measured and compared gene expression levels between siLEF1, siNT, and non-transfected (NTC) Jurkat cells by microarray analysis, which revealed differentially expressed genes (DEGs), potential targets of LEF1. The most significant 10 DEGs included histone genes and DHRS2 (Figure 2). The $\mathrm{GO}$ enrichment analysis of the significantly downregulated genes in siLEF1 cells showed the distribution of the most abundant categories (Table 1). After GO enrichment analysis, we searched for the associated pathways for the DEGs using the KEGG and found that metabolic pathways, pathways in cancer, viral carcinogenesis, transcriptional dysregulation in cancer, mitogen-activated protein kinase signaling, and the PI3K-Akt pathway were among the aberrantly expressed signaling pathways in LEF1downregulated cells (Table 2).

We verified our microarray results by comparison of DHRS2 gene expressions among siLEF1, siNT, and NTC cells by qRT-PCR.

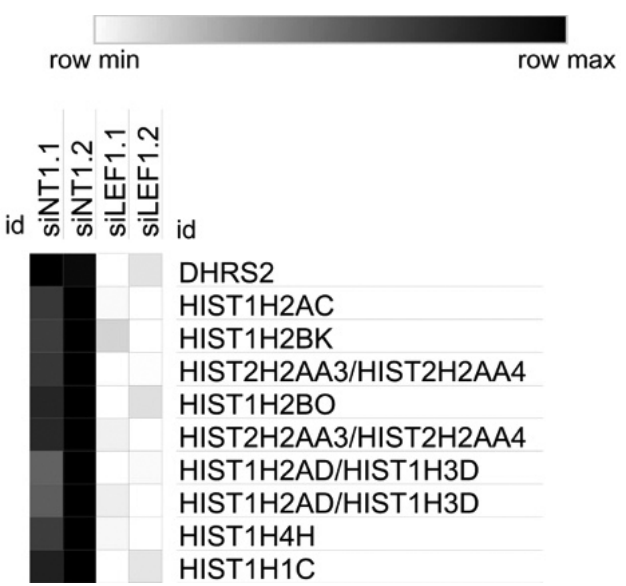

Figure 2. Heatmap of the most significant 10 DEGs. siNT: Nontargeting siRNA-transfected cells, siLEF1: LEF1 siRNA-transfected cells.

\begin{tabular}{|l|l|l|l|l|l|}
\hline Table 1. Top 10 most enriched GO terms for downregulated genes in LEF1 knockdown cells. \\
\hline Category & Term & Count & $\%$ & p-value & FDR \\
\hline GOTERM_MF_DIRECT & Protein binding & 117 & 52.9 & $4.9 \mathrm{E}-4$ & $6.6 \mathrm{E}-1$ \\
\hline GOTERM_CC_DIRECT & Nucleus & 87 & 39.4 & $9.9 \mathrm{E}-7$ & $1.2 \mathrm{E}-3$ \\
\hline GOTERM_CC_DIRECT & Nucleoplasm & 57 & 25.8 & $1.7 \mathrm{E}-7$ & $2.2 \mathrm{E}-4$ \\
\hline GOTERM_MF_DIRECT & DNA binding & 42 & 19.0 & $2.9 \mathrm{E}-7$ & $3.9 \mathrm{E}-4$ \\
\hline GOTERM_MF_DIRECT & Protein heterodimerization activity & 30 & 13.6 & $1.4 \mathrm{E}-14$ & $1.9 \mathrm{E}-11$ \\
\hline GOTERM_CC_DIRECT & Nucleosome & 23 & 10.4 & $3.2 \mathrm{E}-24$ & $4.0 \mathrm{E}-21$ \\
\hline GOTERM_BP_DIRECT & $\begin{array}{l}\text { Negative regulation of transcription from } \\
\text { RNA polymerase II promoter }\end{array}$ & 19 & 8.6 & $5.7 \mathrm{E}-4$ & $9.2 \mathrm{E}-1$ \\
\hline GOTERM_BP_DIRECT & Nucleosome assembly & 17 & 7.7 & $1.1 \mathrm{E}-13$ & $1.8 \mathrm{E}-10$ \\
\hline GOTERM_CC_DIRECT & Nuclear nucleosome & 13 & 5.9 & $1.3 \mathrm{E}-14$ & $1.7 \mathrm{E}-11$ \\
\hline GOTERM_CC_DIRECT & Nuclear chromatin & 10 & 4.5 & $1.6 \mathrm{E}-4$ & $2.0 \mathrm{E}-1$ \\
\hline
\end{tabular}

Table 2. Top 10 KEGG pathways according to the number of associated DEGs.

\begin{tabular}{|l|l|l|}
\hline Pathway id & Pathway name & No. of genes \\
\hline hsa01100 & Metabolic pathways & 51 \\
\hline hsa05034 & Alcoholism & 42 \\
\hline hsa05322 & Systemic lupus erythematosus & 39 \\
\hline hsa05200 & Pathways in cancer & 36 \\
\hline hsa05168 & Herpes simplex virus 1 infection & 31 \\
\hline hsa05203 & Viral carcinogenesis & 31 \\
\hline hsa05202 & Transcriptional misregulation in cancer & 26 \\
\hline hsa04010 & MAPK signaling pathway & 26 \\
\hline hsa04151 & Pl3K-Akt signaling pathway & 25 \\
\hline hsa04217 & Necroptosis & 20 \\
\hline
\end{tabular}


Twenty-four hours after transfection, compared to siNT cells, an 84\% decrease was observed in mRNA levels of DHRS2 in siLEF1 cells (Figure 3).

Protein level verification of microarray and qRT-PCR results was conducted by western blotting. Protein levels of LEF1 and DHRS2 were determined to investigate the LEF1 and DHRS2 genes' downregulation in siLEF1 cells compared to siNT and NTC cells. LEF1 protein levels were almost undetectable $24 \mathrm{~h}$ after transfection (Figure 4) and were reduced by 1.8 -fold $48 \mathrm{~h}$ after transfection in siLEF1 cells compared to siNT cells (Figure 4). The protein level of DHRS2 was 2.1-fold reduced in siLEF1 cells compared to siNT cells $24 \mathrm{~h}$ after transfection and the suppression persisted $48 \mathrm{~h}$ after transfection (Figure 4). LEF1

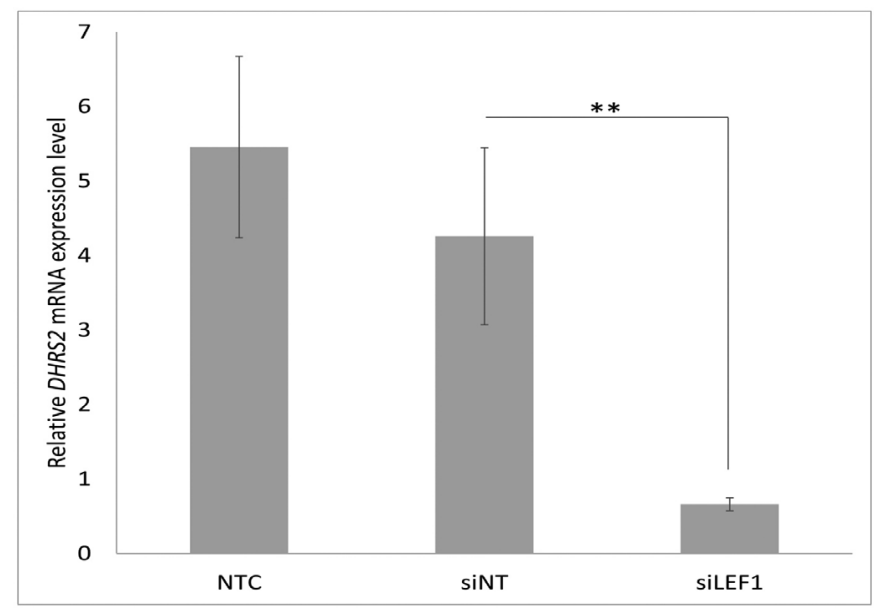

Figure 3. Expression of DHRS2 siRNA-transfected Jurkat cells by quantitative polymerase chain reaction. NTC: Non-transfected cells, siNT: non-targeting siRNA-transfected cells, siLEF1: LEF1 siRNA-transfected cells. ${ }^{* *}: p=0.001$.

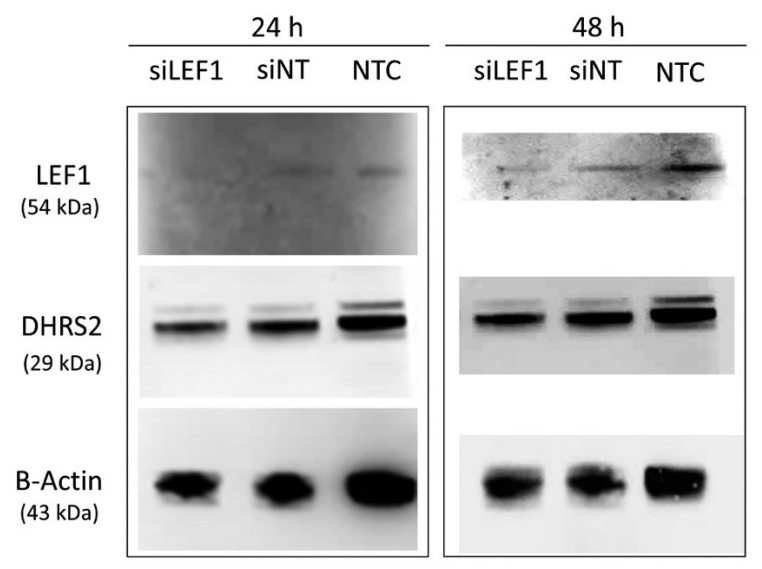

Figure 4. LEF1 and DHRS2 protein levels in siLEF1, siNT, and NTC cells $24 \mathrm{~h}$ and $48 \mathrm{~h}$ after transfection. NTC: Non-transfected cells, siNT: non-targeting siRNA-transfected cells, siLEF1: LEF1 siRNAtransfected cells. and DHRS2 protein levels obtained by western blotting were quantified by normalizing the protein expression levels to $\beta$-actin expression (Figure 5).

\section{Discussion}

Although there have been many studies on T-ALL, the underlying molecular mechanisms of this disease have yet to be revealed. In this study, we examined the potential role of the transcription factor LEF1 in T-ALL by determining its target genes and regulation mechanisms. We have compared the gene expression levels of siLEF1, siNT, and NTC Jurkat cells by microarray analysis in order to identify DEGs, which are potential targets of LEF1 (https:// www.ncbi.nlm.nih.gov/geo/query/acc.cgi?acc=GSE129917). One of the most enriched pathways for downregulated genes was "Pathways in cancer-hsa05200," which is consistent with the association of LEF1 expression with a variety of cancers. The most significant 10 DEGs included DHRS2 (HEP27) and histone genes (Figure 2). As LEF1 is known to regulate cell cycle regulators and cellular proliferation genes, the accompanying downregulation of histone genes in LEF1 knockdown cells reflects the relationship between $L E F 1$ and cellular proliferation. We further focused on DHRS2, which is a member of the shortchain dehydrogenase/reductase enzyme family that has activity toward steroids, retinoids, prostaglandins, and xenobiotics $[29,30]$. Thus, to verify our microarray results, we analyzed the expression levels of LEF1 and DHRS2 in siLEF1, siNT, and NTC cells using qRT-PCR. Additionally, protein levels of these two genes were evaluated by western blotting. Both RNA and protein level analyses confirmed our microarray results. We also searched the GEO database and found that the DHRS2 gene is upregulated in colon cancer cells treated with the adenoviral LEF1 expression vector (GEO accession number: GSE3229), which is consistent with our results.

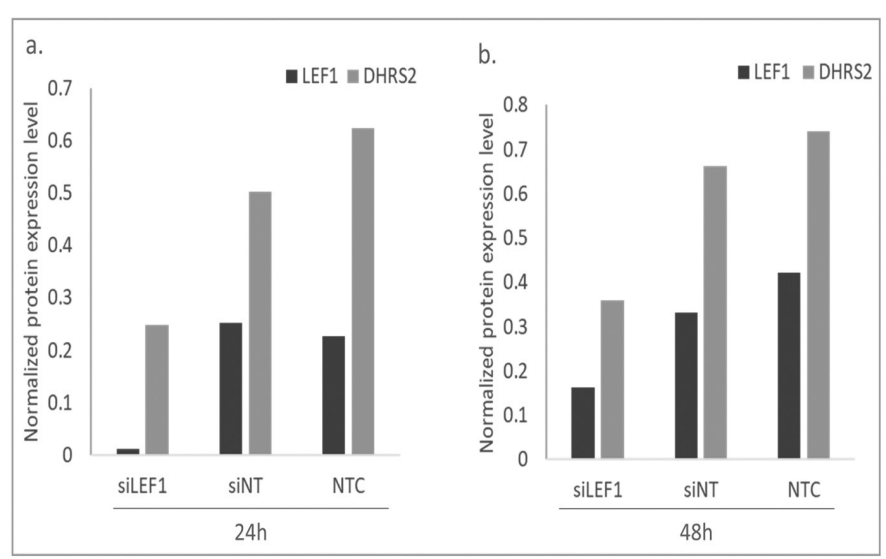

Figure 5. LEF1 and DHRS2 protein levels normalized by using $\beta$-actin protein expression level: a) $24 \mathrm{~h}$ after transfection, b) $48 \mathrm{~h}$ after transfection. NTC: Non-transfected cells, siNT: nontargeting siRNA-transfected cells, siLEF1: LEF1 siRNA-transfected cells. 
DHRS2 is suggested to be a tumor suppressor gene in different tumor types, including nasopharyngeal carcinoma [31,32], gastrointestinal stromal tumors [33,34], metastatic lung adenocarcinomas [35], esophageal squamous cell carcinoma [30], and renal cancer [36]. Previous reports showed that the DHRS2 enzyme interacts with MDM2, a protein responsible for the negative regulation of the p53 tumor suppressor gene $[37,38,39]$. Similarly, it is also known that one of the alternatively spliced transcripts of CDKN2 (ARF) antagonizes MDM2-dependent p53 degradation [40]. Furthermore, LEF1 inactivation has been associated with biallelic INK4a/ARF deletions in T-ALL [21]. Additionally, it has been reported that overexpression of $\beta$-catenin, a coactivator of $L E F 1$, results in p53 accumulation through upregulation of $A R F[41,42]$ and the $\mathrm{N}$-terminal of LEF1 ( $\triangle \mathrm{NLef1)}$, which acts as a tumor promoter by preventing accumulation of p53 in human and mouse sebaceous tumors, and $A R F$ downregulation is likely to be responsible for this mechanism [43]. Thus, it may be possible that the activation of $\mathrm{p} 53$ accumulation by $\beta$-catenin and LEF1 depends on not only ARF but also DHRS2 upregulation. However, further functional studies are needed to investigate these relationships and understand the molecular mechanism.

p53 mutations are known to be frequent in T-ALL $[44,45]$. In Jurkat cells, a heterozygous, stop-gained mutation in exon 6 of the $p 53$ gene (R196* or rs397516435) considered to be important in leukemogenesis or in the tumorigenic progression of leukemic T cells has been reported [46]. Thus, as Jurkat cells are p53mutant, we could not detect p53 in western blotting analysis. Our findings imply that DHRS2-mediated p53 accumulation does not occur in p53-mutant Jurkat cells and overexpression of LEF1 may show oncogenic effects via overexpression of its downstream target, $M Y C$, which is known to play a major role in T-ALL $[6,47]$. It has been reported that LEF1 is overexpressed in 30\% of adult T-ALL patients [16]. On the other hand, LEF1 microdeletion was detected in $11 \%$ of adult T-ALL cases [21]. These contradictory observations might result from the altered LEF1 effects due to cooperative tumorigenic genetic events. It is known that both oncogenes and tumor suppressor genes are targeted by LEF1, which suggests that cooperative genetic events in its downstream genes may determine the final outcome of LEF1 action. Our results suggest that DHRS2 is one of the tumor suppressor targets of LEF1 in the Jurkat human T-cell leukemia cell line. Based on these results, one may speculate that the inactivation of LEF1 may be causing the prevention of the tumor suppressor effect of DHRS2 in T cells and contributing to leukemogenesis.

\section{Conclusion}

In this study, we demonstrate that LEF1 positively regulates DHRS2 gene expression in the Jurkat human T-cell leukemia cell line and thus provide new insight into the LEF1-p53 link in
T-cell leukemogenesis. Our findings suggest a tumor-suppressive role for LEF1 by the regulation of the downstream DHRS2-p53 signaling pathway, which explains the molecular mechanism behind the observation of LEF1-induced p53 accumulation. This study supports the growing evidence that LEF1 plays a regulatory role in T-cell proliferation and differentiation and its dysregulation contributes to the development of T-ALL. The main limitations of our study are that it was performed by using only one cell line, was not validated in T-ALL patients, and requires further functional investigations to confirm the implications of its results, including the potential role of DHRS2 in T-ALL and its interactions with LEF1.

\section{Ethics}

Ethics Committee Approval: This article does not contain any studies with human participants or animals performed by any of the authors.

Informed Consent: This study does not involve human subjects and, thus, informed consent is not required.

\section{Authorship Contributions}

Study Design: S.S.E., N.A.; Ç.G.; Processing: Z.E., M.S., B.S.; Analysis or Interpretation: S.S.E, C.G.E., B.S., N.A.; Writing: S.S.E, C.G.E.

Conflict of Interest: The authors declare no conflicts of interest.

Financial Disclosure: This work was supported by the Scientific Research Projects Coordination Unit of İstanbul University (Grant No. 3092).

\section{References}

1. McMahon CM, Luger S. Relapsed T cell ALL: current approaches and new directions. Curr Hematol Malig Rep 2019;14;83-93.

2. Bongiovanni D, Saccomani V, Piovan E. Aberrant signaling pathways in T-cell acute Iymphoblastic leukemia. Int J Mol Sci 2017;18:1904.

3. Goldberg JM, Silverman LB, Levy DE, Dalton VK, Gelber RD, Lehmann L, Cohen HJ, Sallan SE, Asselin BL. Childhood T-cell acute lymphoblastic leukemia: the Dana-Farber Cancer Institute acute lymphoblastic leukemia consortium experience. J Clin Oncol 2003;21:3616-3622.

4. Oudot C, Auclerc MF, Levy V, Porcher R, Piguet C, Perel $Y$, Gandemer V, Debre M, Vermylen C, Pautard B, Berger C, Schmitt C, Leblanc T, Cayuela JM, Socie G, Michel G, Leverger G, Baruchel A. Prognostic factors for leukemic induction failure in children with acute lymphoblastic leukemia and outcome after salvage therapy: the FRALLE 93 study. J Clin Oncol 2008;26:1496-1503.

5. Van Vlierberghe $P$, Ferrando $A$. The molecular basis of $T$ cell acute lymphoblastic leukemia. J Clin Invest 2012;122:3398-3406.

6. Weng AP. c-Myc is an important direct target of Notch1 in T-cell acute lymphoblastic leukemia/lymphoma. Genes Dev 2006;20:2096-2109.

7. Fogelstrand $L$, Staffas $A$, Wasslavik $C$, Sjögren $H$, Söderhäll $S$, Frost BM, Forestier E, Degerman S, Behrendtz M, Heldrup J, Karrman K, Johansson B, Heyman M, Abrahamsson J, Palmqvist L. Prognostic implications of mutations in NOTCH1 and FBXW7 in childhood T-all treated according to the NOPHO ALL-1992 and ALL-2000 protocols. Pediatr Blood Cancer 2014;61:424-430. 
8. Roti G, Stegmaier K. Targeting NOTCH1 in hematopoietic malignancy. Crit Rev Oncog 2011;16:103-115.

9. Reya $\mathrm{T}$, Clevers $\mathrm{H}$. Wht signalling in stem cells and cancer. Nature 2005;434:843-850.

10. Grumolato L, Liu G, Haremaki T, Mungamuri SK, Mong P, Akiri G, LopezBergami P, Arita A, Anouar Y, Mlodzik M, Ronai ZA, Brody J, Weinstein DC, Aaronson SA. $\beta$-Catenin-independent activation of TCF1/LEF1 in human hematopoietic tumor cells through interaction with ATF2 transcription factors. PLoS Genet 2013;9:e1003603.

11. Petropoulos K, Arseni N, Schessl C, Stadler CR, Rawat VP, Deshpande AJ, Heilmeier B, Hiddemann W, Quintanilla-Martinez L, Bohlander SK, FeuringBuske $M$, Buske C. A novel role for Lef-1, a central transcription mediator of Wnt signaling, in leukemogenesis. J Exp Med 2008;205:515-522.

12. Gutierrez A Jr, Tschumper RC, Wu X, Shanafelt TD, Eckel-Passow J, Huddleston PM 3rd, Slager SL, Kay NE, Jelinek DF. LEF-1 is a prosurvival factor in chronic lymphocytic leukemia and is expressed in the preleukemic state of monoclonal B-cell lymphocytosis. Blood 2010;116:2975-2983.

13. Metzeler $K H_{1}$, Heilmeier $B$, Edmaier $K E$, Rawat VP, Dufour $A$, Döhner $K$, Feuring-Buske $M$, Braess J, Spiekermann $K$, Büchner T, Sauerland $M C$, Döhner $\mathrm{H}$, Hiddemann W, Bohlander SK, Schlenk RF, Bullinger L, Buske C. High expression of lymphoid enhancer-binding factor-1 (LEF1) is a novel favorable prognostic factor in cytogenetically normal acute myeloid leukemia. Blood 2012;120:2118-2126.

14. Kühnl A, Gökbuget N, Kaiser M, Schlee $C$, Stroux A, Burmeister T, Mochmann LH, Hoelzer D, Hofmann WK, Thiel E, Baldus CD. Overexpression of LEF1 predicts unfavorable outcome in adult patients with B-precursor acute lymphoblastic leukemia. Blood 2011;118:6362-6367.

15. Jamieson CH, Ailles LE, Dylla SJ, Muijtjens M, Jones C, Zehnder JL, Gotlib J, Li K, Manz MG, Keating A, Sawyers CL, Weissman IL. Granulocyte-macrophage progenitors as candidate leukemic stem cells in blast-crisis CML. N Engl J Med 2004;351:657-667.

16. Guo X, Zhang R, Liu J, Li M, Song C, Dovat S, Li J, Ge Z. Characterization of LEF1 high expression and novel mutations in adult acute lymphoblastic leukemia. PLoS One 2015;10:e0125429.

17. Wu W, Zhu H, Fu Y, Shen W, Miao K, Hong M, Xu W, Fan L, Young KH, Liu P, Li J. High LEF1 expression predicts adverse prognosis in chronic lymphocytic leukemia and may be targeted by ethacrynic acid. Oncotarget 2016;7:21631.

18. Jia M, Zhao HZ, Shen HP, Cheng YP, Luo ZB, Li SS, Zhang JY, Tang YM. Overexpression of lymphoid enhancer binding factor 1 (LEF1) is a novel favorable prognostic factor in childhood acute lymphoblastic leukemia. Int J Lab Hematol 2015;37:631-640.

19. Albano $F$, Zagaria $A$, Anelli $L$, Orsini $P$, Minervini $C F$, Impera $L$, Casieri $P$, Coccaro N, Tota G, Brunetti C, Minervini A, Pastore D, Carluccio P, Mestice A, Cellamare A, Specchia G. Lymphoid enhancer binding factor-1 (LEF1) expression as a prognostic factor in adult acute promyelocytic leukemia. Oncotarget 2014;5:649.

20. Fu Y, Zhu H, Wu W, Xu J, Chen T, Xu B, Qian S, Li J, Liu P. Clinical significance of lymphoid enhancer-binding factor 1 expression in acute myeloid leukemia. Leuk Lymphoma 2014;55:371-377.

21. Gutierrez A, Sanda T, Ma W, Zhang J, Grebliunaite R, Dahlberg S, Neuberg D, Protopopov A, Winter SS, Larson RS, Borowitz MJ, Silverman LB, Chin L, Hunger SP, Jamieson C, Sallan SE, Look AT. Inactivation of LEF1 in T-cell acute lymphoblastic leukemia. Blood 2010;115:2845-2851.

22. Noronha EP, Marques LVC, Andrade FG, Thuler LCS, Terra-Granado E, Pombode-Oliveira MS; Brazilian Collaborative Study Group of Acute Leukemia. The profile of immunophenotype and genotype aberrations in subsets of pediatric T-cell acute lymphoblastic leukemia. Front Oncol 2019;9:1-10.

23. Clough $E_{1}$ Barrett $T$. The gene expression omnibus database. Methods Mol Biol 2016;1418:93-110.

24. Benjamini Y, Hochberg Y. Controlling the false discovery rate: a practical and powerful approach to multiple testing. J R Stat Soc Ser B 199;557:289300.

25. Huang DW, Sherman BT, Lempicki RA. Systematic and integrative analysis of large gene lists using DAVID bioinformatics resources. Nat Protoc 2009;4:44-57.

26. Huang DW, Sherman BT, Lempicki RA. Bioinformatics enrichment tools: paths toward the comprehensive functional analysis of large gene lists. Nucleic Acids Res 2009;37:1-13.

27. Mi $H$, Muruganujan $A$, Ebert $D$, Huang $X$, Thomas PD. PANTHER version 14 : More genomes, a new PANTHER G0-slim and improvements in enrichment analysis tools. Nucleic Acids Res 2019;47:419-426.

28. Kanehisa M, Goto S. KEGG: Kyoto Encyclopedia of Genes and Genomes. Nucleic Acids Res 2000;28:27-30.

29. Shafqat N, Shafqat J, Eissner G, Marschall HU, Tryggvason K, Eriksson U,

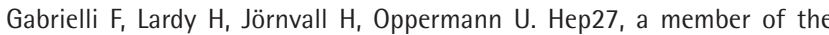
short-chain dehydrogenase/reductase family, is an NADPH-dependent dicarbonyl reductase expressed in vascular endothelial tissue. Cell Mol Life Sci 2006:63:1205-1213.

30. Zhou Y, Wang L, Ban X, Zeng T, Zhu Y, Li M, Guan XY, Li Y. DHRS2 inhibits cell growth and motility in esophageal squamous cell carcinoma. Oncogene 2018;37:1086-1094.

31. Mutirangura A, Pornthanakasem W, Sriuranpong V, Supiyaphun P, Voravud $\mathrm{N}$. Loss of heterozygosity on chromosome 14 in nasopharyngeal carcinoma. Int J Cancer 1998;78:153-156.

32. Cheng Y, Ko JMY, Lung HL, Lo PHY, Stanbridge EJ, Lung ML. Monochromosome transfer provides functional evidence for growth-suppressive genes on chromosome 14 in nasopharyngeal carcinoma. Genes Chromosom Cancer 2003;37:359-368.

33. El-Rifai W, Sarlomo-Rikala M, Andersson LC, Miettinen M, Knuutila S. Highresolution deletion mapping of chromosome 14 in stromal tumors of the gastrointestinal tract suggests two distinct tumor suppressor loci. Genes Chromosom Cancer 2000;27:387-391.

34. Debiec-Rychter M, Lasota J, Sarlomo-Rikala M, Kordek R, Miettinen M. Chromosomal aberrations in malignant gastrointestinal stromal tumors. Cancer Genet Cytogenet 2001;128:24-30.

35. Goeze A, Schlüns K, Wolf G, Thäsler Z, Petersen S, Petersen I. Chromosomal imbalances of primary and metastatic lung adenocarcinomas. J Pathol 2002;196:8-16.

36. Fang L, Cheng Q, Liu W, Zhang J, Ge Y, Zhang Q, Li L, Liu J, Zheng J. Selective effects of a fiber chimeric conditionally replicative adenovirus armed with hep27 gene on renal cancer cell. Cancer Biol Ther 2016;17:664-673.

37. Deisenroth $C$, Thorner AR, Enomoto T, Perou CM, Zhang Y. Mitochondrial HEP27 is a c-Myb target gene that inhibits Mdm2 and stabilizes p53. Mol Cell Biol 2010;30:3981-3993.

38. Oda T, Sekimoto T, Kurashima K, Fujimoto M, Nakai A, Yamashita T. Acute HSF1 depletion induces cellular senescence through the MDM2-p53-p21 pathway in human diploid fibroblasts. J Cell Sci 2018;131:jcs210724.

39. Han Y, Song C, Wang J, Tang H, Peng Z, Lu S. HOXA13 contributes to gastric carcinogenesis through DHRS2 interacting with MDM2 and confers 5-FU resistance by a p53-dependent pathway. Mol Carcinog 2018;57:722-734.

40. Sherr CJ, Weber JD. The ARF/p53 pathway. Curr Opin Genet Dev 2000:10:9499.

41. Damalas A. Excess beta-catenin promotes accumulation of transcriptionally active p53. EMBO J 1999;18:3054-3063.

42. Damalas A. Deregulated beta-catenin induces a p53- and ARF-dependent growth arrest and cooperates with Ras in transformation. EMBO J $2001 ; 20: 4912-4922$

43. Niemann C, Owens DM, Schettina P, Watt FM. Dual role of inactivating Lef1 
mutations in epidermis: tumor promotion and specification of tumor type. Cancer Res 2007;67:2916-2921.

44. Yeargin J, Cheng J, Yu AL, Gjerset R, Bogart M, Haas M. P53 mutation in acute $T$ cell lymphoblastic leukemia is of somatic origin and is stable during establishment of T cell acute lymphoblastic leukemia cell lines. J Clin Invest 1993;91:2111-2117.

45. Tawara M, Hogerzeil SJ, Yamada Y, Takasaki Y, Soda H, Hasegawa H, Murata K, Ikeda S, Imaizumi Y, Sugahara K, Tsuruda K, Tsukasaki K, Tomonaga M, Hirakata Y, Kamihira S. Impact of p53 aberration on the progression of adult T-cell leukemia/lymphoma. Cancer Lett 2006;234:249-255.
46. Stengel A, Schnittger $S$, Weissmann $S$, Kuznia $S$, Kern W, Kohlmann A, Haferlach T, Haferlach C. TP53 mutations occur in $15.7 \%$ of ALL and are associated with MYC-rearrangement, low hypodiploidy, and a poor prognosis. Blood 2014;124:251-258.

47. Palomero $T$, Lim WK, Odom DT, Sulis ML, Real PJ, Margolin A, Barnes KC, O'Neil J, Neuberg D, Weng AP, Aster JC, Sigaux F, Soulier J, Look AT, Young RA, Califano A, Ferrando AA. NOTCH1 directly regulates c-MYC and activates a feed-forward-loop transcriptional network promoting leukemic cell growth. Proc Natl Acad Sci U S A 2006;103:18261-18266. 